\title{
CZYNNIKI LOKALIZACJI CENTRUM LOGISTYCZNEGO NA RYNKU CHIŃSKIM Z WYKORZYSTANIEM METODY PESTE
}

\begin{abstract}
Rynek chiński od 1978 roku, a więc od momentu rozpoczęcia przemian i wprowadzania reform w Chinach,szeroko otworzył się na wymianę międzynarodową, a tempo wzrostu gospodarczego w tym kraju znacznie wzrosło. Według produktu krajowego brutto (PKB) per capita, Chiny wykazują stały wzrost. Chiński produkt krajowy brutto per capita po skorygowaniu parytetu siły nabywczej w roku 2014 wyniósł 12608.87 dolarów a średnie PKB per capita od roku 1990 do 2014 wyniosło 5476,62 dolarów ${ }^{3}$.Mimo, że w ostatnich latach tempo wzrostu PKB jest nieco słabsze, to w dalszym ciągu handel wewnętrzny oraz międzynarodowy generuje zapotrzebowanie na budowę centrów logistycznych, czyliobiektów przestrzennych, spełniających konkretne funkcje, wraz z właściwą organizacją oraz infrastrukturą. Realizowane są w nich różnorodne usługi logistyczne, do których można zaliczyć: magazynowanie, rozdzielanie, przyjmowanie i wydawanie towarów ${ }^{4}$. Typowe centrum logistyczne powinno wobec tego posiadać takie obiekty jakmagazyny, kolejowe terminale kontenerowe, place składowe, a także miejsca świadczenia usług celnych i inne. Lokalizację centrów można wyznaczyć za pomocą tradycyjnych metod. Do znanych oraz najczęściej wykorzystywanych metod wspomagających proces wyznaczania lokalizacji centrum logistycznego należą takie metody jak:metoda niehierarchicznej analizy skupień, przekształcona formuła problemu transportowego, czyli model Huffa oraz wyznaczenie promienia obszaru ciążenia Natomiast metodą, która pozwala w sposób kompleksowy uwzględnić różnorodne czynniki wpływające na lokalizację, jest metoda PESTE.

Słowa kluczowe: centrum logistyczne, czynniki lokalizacji, metoda PESTE.
\end{abstract}

\section{WPROWADZENIE}

Lokalizacja centrum logistycznegopolega na określeniu jego położenia geograficznego w przestrzeni. Na lokalizację mają wpływ następujące czynniki ${ }^{5}$ :

1. Produkcyjne:

- źródła surowców,

- dostępność energii,

- możliwości transportowe,

- siła robocza itp.

\footnotetext{
${ }^{1}$ Dr hab. Andrzej Gazda, prof. PRz, Katedra Systemów Zarządzania i Logistyki, Wydział Zarządzania, Politechnika Rzeszowska, autor korespondencyjny: e-mail: agazda@prz.edu.pl ${ }^{2}$ Mgr inż. Gabriela Popek, absolwentka Wydziału Zarządzania Politechniki Rzeszowskiej ${ }^{3}$ China,gdp-per-capita-ppp, http://www.tradingeconomics.com/, 29.12.2015.

${ }^{4}$ I. Fechner, Centra logistyczne. Cel-Realizacja - Przyszłość, ILiM, Poznań 2004, s. 14.

${ }^{5}$ D. Malindžák, A. Gazda, Podstawy logistyki w przedsiębiorstwie, Oficyna Wydawnicza Politechniki Rzeszowskiej, Rzeszów 2011, s. 57.
} 
2. Handlowe:

- poziom podatków,

- rynek,

- możliwości komunikacyjne,

- cena itp.

3. Społeczne:

- bezrobocie,

- $\quad$ tradycja produkcyjna, przemysłowa itp.

Jedną z metod lokalizacji jest model niehierarchicznej analizy skupień. Podstawowym kryterium tej metody jest wyznaczenie miejsca centrum logistycznego, w którym koszty związane z jego eksploatacją będą najniższe. Istotne dla obliczeń jest określenie zbioru elementów warunkujących funkcjonowanie centrum. Można do nich zaliczyć liczbę magazynów oraz przedsiębiorstw transportowych ${ }^{6}$.

Przy pomocy metody k - średnich zostają utworzone możliwie odmienne skupienia.Następnie obiekty są przenoszone pomiędzy skupieniami, do czasu zoptymalizowania zmienności pomiędzy skupieniami oraz wewnątrz skupień. Podobieństwo wewnątrz skupienia powinno być jak największe, natomiast osobne skupienia powinny być od siebie maksymalnie różne.

Kolejną metodą, wykorzystywaną przy wyborze lokalizacji nowego centrum logistycznego, jest przekształcona formuła problemu transportowego, czylimodel Huffa. W metodzie tej zakłada się, że lokalizacja współpracujących przedsiębiorstw oraz jednostkowe koszty transportu są znane. Minimalizacja kosztów logistycznych w samym centrum jak i we współpracujących przedsiębiorstwach jest głównym celem budowy danego centrum. Metoda Huffa zakłada również zapewnienie wysokiego poziomu obsługi klienta. Zgodnie ze wzorem (1) zostaje wyznaczona funkcja kosztu ${ }^{7}$.

$$
\mathrm{K}=\cdot \sum_{\mathrm{i}=1}^{\mathrm{n}} \mathrm{k}_{\mathrm{i}}^{\mathrm{A}} * \mathrm{a}_{\mathrm{i}} * \mathrm{~d}_{\mathrm{io}} * \sum_{\mathrm{j}=1}^{\mathrm{n}} \mathbf{k}_{\mathrm{j}}^{\mathrm{B}} * \mathrm{~b}_{\mathrm{j}} * \mathrm{~d}_{\mathrm{oj}}(1)
$$

$\mathrm{k}_{\mathrm{i}}^{\mathrm{A}}$ - koszt i-tego transportu do centrum z przedsiębiorstwa współpracującego A,

$\mathrm{k}_{\mathrm{j}}^{\mathrm{B}}$ - koszt j-tego transportu do CL z przedsiębiorstwa współpracującego B,

$\mathrm{a}_{\mathrm{i}}$ - prognozy rocznych dostaw do CL z przedsiębiorstw współpracujących,

$\mathrm{b}_{\mathrm{j}}$ - prognozy rocznego zapotrzebowania klientów,

$\mathrm{d}_{\mathrm{io}}$ - odległość między centrum a współpracującymi przedsiębiorstwami, .

$\mathrm{d}_{\text {ojj- }}$ odległość centrum od współpracujących przedsiębiorstw, wyznaczona zostaje ze wzorów odległości euklidesowej lub metryki prostokątnej.

Można też wykorzystywać metodę polegającą na wyznaczeniu promienia obszaru ciążenia (wzór 2). Przy ustalaniu lokalizacji wyznacza się zbiór wag $\mathrm{w}_{1}, \mathrm{w}_{2}, \ldots, \mathrm{w}_{\mathrm{n}}$ oraz odległości centrum grawitacyjnego od współpracujących przedsiębiorstw - kolejno $\mathrm{d}_{1}, \mathrm{~d}_{2}$, $\ldots, \mathrm{d}_{\mathrm{n}}$. Położenie nowego obiektu logistycznego wyznacza się w następujący sposób ${ }^{8}$ :

${ }^{6}$ B. Skowron-Grabowska, Centra logistyczne w tańcuchach dostaw, PWE Warszawa 2010, s. 111.

${ }^{7}$ B. Skowron-Grabowska, op. cit., s. 111 - 112.

${ }^{8}$ Ibidem, s. 112. 


$$
\mathrm{F}_{1}=\mathrm{W}_{1} * \mathrm{~d}_{1} ; \mathrm{F}_{2}=\mathrm{W}_{2} * \mathrm{~d}_{2} ; \ldots ; \mathrm{F}_{\mathrm{n}-1}=\mathrm{W}_{\mathrm{n}-1} * \mathrm{~d}_{\mathrm{n}-1} ; \mathrm{F}_{\mathrm{n}}=\mathrm{W}_{\mathrm{n}} * \mathrm{~d}_{\mathrm{n}}(2)
$$

W celu wyznaczenia optymalnego położenia centrum logistycznego powinno zostać spełnione równanie zgodnie ze wzorem (3).

$$
\mathrm{F}_{1}+\mathrm{F}_{2}+\cdots+\mathrm{F}_{\mathrm{n}-1}+\mathrm{F}_{\mathrm{n}}=0
$$

Wzór (3) pokazuje, że wszystkie wagi są ze sobą powiązane.Dla zachowania równości każda zmiana wagi $\mathrm{w}$ jednym kierunku, jest następstwem zmiany wagi w przeciwnym kierunku. Równocześnie wraz ze wzrostem wagi odzwierciedlona zostaje coraz mniejsza odległość przedsiębiorstw od centrum. W odwrotnym przypadku wraz ze wzrostem odległości od centrum następuje spadek wielkości wag. Sposób ten pozwala zachować bilans przedstawiony we wzorze (3). Koncepcja ta największe wagi przyznaje obiektom znajdującym się $\mathrm{w}$ najbliższej odległości, natomiast najmniejsze wagi obiektom najbardziej oddalonym.

Metoda, która polega na uwzględnieniu i analizie wielu czynników nosi nazwę PEST, PESTE, lub PESTEL. Jest to metoda, która służy do badania makrootoczenia przedsiębiorstwa. Natomiast $\mathrm{w}$ dalszej części opracowania podjęto próbę i pokazano możliwości wykorzystania tej metody w procesie lokalizacji centrum logistycznego.

\section{CHARAKTERYSTYKA METODY PESTE}

Analiza PEST (PESTE lub PESTEL) jest narzędziem, które służy do obserwacji i badania otoczenia przedsiębiorstwa. Podstawowa wersja analizy może zostać rozszerzona o dodatkowy element $\mathrm{E}$ (ang. Environment), czyli środowisko a także element L (ang. Legal), a więc prawo.

Analiza zajmuje się badaniem różnych uwarunkowań makrootoczenia, które wpływają bądź mogą wpływać na działalność organizacji. Punktem wyjścia jest wyodrębnienie podstawowych czynników, które mogą mieć wpływ na funkcjonowanie danego przedsiębiorstwa. Prawidłowe przeprowadzenie badania metodą PEST stwarza podstawy do określenia perspektyw i opracowania strategii działania długofalowego oraz może zostać wykorzystane do dalszych analiz np. analizy SWOT.

Każdy przedsiębiorca wchodzący na nowy rynek powinien rozważyć wykorzystanie tego narzędzia badania otoczenia, ponieważ nie można stworzyć strategii działania, nie biorąc pod uwagę sytuacji ekonomicznej danego kraju czy regionu, w którym chce inwestować i funkcjonować. Przykładem może być koszt pracy, na przykład w Chinach jest on kilkukrotnie niższy od standardów panujących w Europie. Należy w tym przypadku uwzględnić również spektrum decyzji politycznych oraz przepisy prawa. Przedsiębiorstwa, które funkcjonują na rynku międzynarodowym muszą liczyć się z tym, iż w różnych częściach świata stanowione prawo jest odmienne. Ważnym aspektem jest także społeczeństwo, jego nastroje, przyzwyczajenia, aktualnie panujące trendy mody oraz demografia.Wszystko to wpływa na aktualny oraz przyszły popyt. Rozwój technologiczny oraz aspekty związane z ochroną środowiska również odgrywają istotną rolę w decyzjach dotyczących rozwoju przedsiębiorstwa.

Zestawieniu i skrupulatnej ocenie poddaje się następujące czynniki (stąd pochodzi też nazwa analizy, akronim wywodzący się z angielskich nazw czynników):

- Political (polityczno - prawne),

- Economic (ekonomiczne), 
- Social (społeczno - kulturowe),

- Technological (technologiczne),

- Environment (środowiskowe).

Analiza odbywa się w trzech następujących etapach:

- W pierwszym kroku określa się najważniejsze czynniki w poszczególnych segmentach otoczenia (a więc technologicznego, społeczno - kulturowego, ekonomicznego, politycznego oraz środowiskowego) i tworzy się listę kontrolną.

- W kolejnym etapie przedsiębiorstwo ocenia, jaki jest wpływ poszczególnych czynników na jego funkcjonowanie. Badaniu poddaje się siłę ich oddziaływania a także określa się ich obecny i prawdopodobny, możliwy wpływ w przyszłości, precyzuje się ich hierarchię oraz dynamikę zmian.

- W ostatnim kroku określa się relacje pomiędzy organizacją a jejmakrootoczeniem, poprzez zestawienie czynników i określeniu jak oddziałują na działalność przedsiębiorstwa. Ostateczny wynik analiz umożliwia opracowanie prognoz oraz działań w celu uniknięcia możliwych zagrożeń oraz wykorzystania istniejących szans ${ }^{9}$.

Wszystkie elementy brane pod uwagę $\mathrm{w}$ analizie PESTE wzajemnie się uzupełniają, dlatego dokonując badań należy rozpatrywać je bardzo dokładnie i kompleksowo.

\section{REALIZACJA METODY PESTE}

Analizę według metody PESTE wykonano dla funkcjonującego na rynku chińskim przedsiębiorstwa $\mathrm{z}$ branży meblarskiej, które mogłoby otworzyć swoje centrum logistyczne w mieście Wuhan, w prowincji Hubei. Firma posiada już swoje oddziały w innych chińskich miastach, jednakże ponowna analiza czynników, które mają bezpośredni wpływ na funkcjonowanie i poprawę jej kondycji jest niezbędna na stosunkowo młodym rynku.

Analizie poddano czynniki determinujące działalność firmy w prowincji Hubei, uwzględniając jednocześnie czynniki o charakterze krajowym oraz globalnym, mające związek ze specyfiką branży meblarskiej.Dla poszczególnych czynników określono ocenę trendu dla przedsiębiorstwa oraz ustalono prawdopodobieństwo wystąpienia skłonności zmiany dla każdego z nich. Określono tendencję tej zmiany, która może mieć charakter:

- wzrostu $(\uparrow)$,

- $\operatorname{regresu}(\downarrow)$,

- bądź stabilizacji $(\rightarrow)$

Każda $\mathrm{z}$ wartości tendencji oddziałuje na przedsiębiorstwo pozytywnie lub negatywnie. Siłę tego oddziaływania oceniono według wzorca:

- Siła oddziaływania pozytywnego:

- bardzo mała: +1 ,

- mała: +2 ,

- średnia: +3 ,

- duża: +4 ,

- bardzo duża: +5 .

\footnotetext{
${ }^{9}$ K. Obłój, Strategia Organizacji. W poszukiwaniu trwatej przewagi konkurencyjnej, PWE,
} Warszawa 2007, s. 211. 
- Siła oddziaływania negatywnego:

- bardzo duża: -5 ,

- duża: -4 ,

- średnia: -3 ,

- mała: -2 ,

- bardzo mała: -1 .

Należy podkreślić, iż elementy oceny i siły wpływu są wartościami zmiennymi. Oceny poszczególnych czynników są subiektywne, przez co mogą być obciążone błędem. Na wynik końcowy wpływa również ocena prawdopodobieństwa, której suma dla każdego z czynników wynosi wartość 1 .

$\mathrm{W}$ ramach realizacji ostatniego etapu analizy $\mathrm{w}$ poszczególnych jej obszarach (polityczno-prawnym, ekonomicznym, społeczno-kulturowym, środowiskowym oraz technologicznym) wyznaczono trendy, które wyróżniają się pozytywnym oraz negatywnym wpływem. Ich zestawienia tworzą kolejno scenariusze: optymistyczny oraz pesymistyczny. Obliczono również średni wpływ czynników, dzięki czemu możliwe było wykonanie także scenariusza najbardziej prawdopodobnego, składającego się $\mathrm{Z}$ elementów o maksymalnym współczynniku prawdopodobieństwa.

Ze względu na objętość publikacji zostanie przedstawiona szczegółowa analiza tylko jednego obszaru, natomiast wszystkie wyniki obliczeń będą przedstawione $\mathrm{w}$ formie tabeli oraz wykresu słupkowego, umożliwiającego dokonanie analiz.

Do obszaru polityczno - prawnego można zaliczyć następujące czynniki:

- stabilność rządów,

- relacje między Chinami a Unią Europejską,

- poziom korupcji,

- poziom biurokracji,

- system podatkowy,

- prawa autorskie w Chinach,

- certyfikacja.

Analiza pierwszego czynnika, czyli stabilność rządów:

- Charakterystyka czynnika: władze państwowe Chińskiej Republiki Ludowej kierowane są przez Komunistyczną Partię Chin (według konstytucji z 1982 roku). Ogólnochińskie Zgromadzenie Przedstawicieli Ludowych (OZPL) jest najważniejszym organem ustrojodawczym oraz ustawodawczym, wybieranym na 5-letnią kadencję. Wszelkimi pracami OZPL zajmuje się Stały Komitet, wydając dekrety oraz niektóre ustawy, ratyfikując umowy międzynarodowe. Władza wykonawcza sprawowana jest przez Radę Państwową (rząd) ${ }^{10}$.

- Powód wystąpienia: zgodnie z konstytucją z 1982 roku faktyczną władzę w Chińskiej Republice Ludowej pełni jedna partia.

- Wpływ czynnika na funkcjonowanie: przychylność władzy bądź jej brak wpływają na rozwój przedsiębiorstw działających na rynku chińskim. Polityka kraju ukierunkowana na rozwój prowincji Hubei stwarza idealne warunki do rozwijania biznesu właśnie w tym obszarze.

\footnotetext{
${ }^{10}$ Chiny. Ustrój polityczny,http://encyklopedia.pwn.pl/haslo/Chiny-Ustrój-polityczny;4573926.html, 16.01.2016.
} 
- Możliwe następstwa: stabilność rządu pozwala na dalszą przychylność władzy wobec inwestycji zagranicznych, a tym samym pomoc w szybszym rozwoju przedsiębiorstwa.

Następnym czynnikiem są relacje między Chinami a Unią Europejską:

- Charakterystyka czynnika: Unia Europejska oraz Chiny to obecnie dwa największe podmioty gospodarcze na świecie. Chiny plasują się na drugim miejscu (zaraz po Stanach Zjednoczonych) największych partnerów handlowych Wspólnoty Europejskiej.

- Powód wystąpienia: w listopadzie 2013 roku podczas szesnastego szczytu gospodarczego Unia Europejska - Chiny ogłoszono podjęcie negocjacji odnoszących się do umowy inwestycyjnej pomiędzy Chinami oraz Unią Europejską. Umowa przewidywała stopniową liberalizację inwestycji a także zniesienie ograniczeń dla inwestorów na wzajemnych rynkach ${ }^{11}$.

- Wpływ czynnika na funkcjonowanie: zapewnienie prostszych oraz bezpieczniejszych ram prawnych dla inwestorów po obu stronach.

- Możliwe następstwa: zerwanie współpracy, utrudniona wymiana handlowa.

Analiza poziomu korupcji:

- Charakterystyka czynnika:Transparency International (TI) to niezależna, międzynarodowa organizacja, która bada wskaźnik globalnej korupcji. Każdego roku publikuje CorruptionPerceptions Index (Indeks Percepcji Korupcji), w 2015 roku badaniem objęła 168 krajów $^{12}$. Na pierwszym miejscu (a więc najmniej skorumpowane) spośród 168 państw znalazła się Dania, a kolejno za nią Finlandia oraz Szwecja. Chiny znajdują się na 83 miejscu a więc w środku rankingu. Z kolei najbardziej skorumpowanymi państwami okazały się Korea Północna i Somalia ${ }^{13}$

- Powód wystąpienia: przyczynami korupcji są m.in.: nadużywanie władzy przez urzędników, brak kontroli nad wypełnianiem procedur oraz brak działań antykorupcyjnych.

- Wpływ czynnika na funkcjonowanie: korupcja to bardzo niebezpieczne zjawisko mogące zagrozić funkcjonowaniu kraju. Politycy, którzy poddają się korupcji przyczyniają się do wyrządzania szkód państwu oraz utrudniają prawidłowe funkcjonowanie przedsiębiorstw.

- Możliwe następstwa: nasilenie korupcji może przyczynić się do obniżenia wiarygodności kraju a tym samym niechęć do prowadzenia działalności gospodarczej na terenie Chin.

Poziom biurokracji w Chinach:

\footnotetext{
${ }^{11}$ Countries and regions, China, http://ec.europa.eu/trade/policy/countries-andregions/countries/china/, 18.01.2016.

${ }^{12}$ Transparency International, https://pl.wikipedia.org/wiki/Transparency_International, 18.01.2016.

${ }^{13}$ Corruption Perceptions Index, http://www.transparency.org/cpi2015, 18.01.2016.
} 
- Charakterystyka czynnika: struktury i systemy aparatu państwowego Chin są czasami przestarzałe, wymagają czasochłonnych i niekiedy zbędnych atestów, co odzwierciedla głęboko zakorzeniona komunistyczna biurokracja ${ }^{14}$.

- Powód wystąpienia: chińskie przepisy prawa są bardzo złożone i często mogą być interpretowane w różnoraki sposób. Rozbudowana biurokracja i jej procedury są uciążliwe oraz niejasne, dając zbyt dużą dowolność w podejmowaniu decyzji przez urzędników.

- Wpływ czynnika na funkcjonowanie: ciągła ewolucja w prawie powoduje, iż przedsiębiorstwa muszą nadążać za wszelkimi zmianami, które często utrudniają rozwój biznesu.

- Możliwe następstwa: konieczność brania pod uwagę i zmagania się ze wszelkimi problemami biurokratycznymi wpływa na zmniejszenie dochodów przedsiębiorstw.

Analiza systemu podatkowego:

- Charakterystyka czynnika: system podatkowy wpływa na rozwój państwa, ponieważ podatki stanowią fundament dochodów budżetu ${ }^{15}$.

- Powód wystąpienia: system składa się z dwóch poziomów podatkowych: podatków lokalnych oraz systemu podatków centralnych m.in. VAT, podatku dochodowego od firm z zagranicznym kapitałem ${ }^{16}$.

- Wpływ czynnika na funkcjonowanie: coraz większy udział inwestycji z udziałem przedsiębiorstw zagranicznych zdecydował, iż chińskie zasady podatkowe uległy znacznym modyfikacjom. Zmiany doprowadziły do ujednolicenia stawek celnych dla przedsiębiorstw z kapitałem zagranicznym oraz stopniowo wpływają na przybliżenie chińskiego systemu podatkowego do standardów międzynarodowych.

- Możliwe następstwa: system podatkowy Chin ulega zmianom jednakże w dalszym ciągu nie należy do prostych. Konsekwencją utrudnień podatkowych może okazać się przeniesienie działalności gospodarczej na teren innego kraju.

Prawa autorskie w Chinach:

- Charakterystyka czynnika: prawa autorskie obejmują ochroną prawa twórcy do modyfikowania oraz powielania jego utworu. Ochrona praw autorskich nie odnosi się jedynie do tzw. sektora artystycznego, lecz do wszystkich gałęzi gospodarki ${ }^{17}$.

- Powód wystąpienia: po przystąpieniu do Światowej Organizacji Handlu oraz umowy Traded-RelatedAspect of IntellectualPropertyRights (TRIPS) Chiny

\footnotetext{
${ }^{14}$ Chinas-levels-of-bureaucracy-have-gotten-ridiculous, http://blogs.wsj.com/chinarealtime/2015/04/17/chinas-levels-of-bureaucracy-have-gottenridiculous-premier-says/, 19.01.2016.

${ }^{15}$ System podatkowy,https://mfiles.pl/pl/index.php/System_podatkowy, 23.01.2016.

${ }^{16}$ Informacje na temat chińskiego prawa gospodarczego, http://www.gochina.gov.pl/index/?id=17e62166fc8586dfa4d1bc0e1742c08b, 23.01.2016.

${ }^{17}$ Copyright_Guide, http://www.china-

iprhelpdesk.eu/sites/all/docs/publications/PL_Copyright_Guide_Aug_2010.pdf, 27.01.2016.
} 
rozpoczęły rozwijanie systemu ochrony praw własności intelektualnej (w tym również patentów oraz praw autorskich) ${ }^{18}$.

- Wpływ czynnika na funkcjonowanie: pomimo przystąpienia Chin do umowy międzynarodowej TRIPS, system prawa własności intelektualnej jest nadal niepełny. Chińscy przedsiębiorcy chętnie kopiują i wykorzystują produkty swojej konkurencji, oferując tym samym podobne wzory po niższych cenach.

- Możliwe następstwa: dalszy brak jednoznacznego uregulowania sprawy dotyczącej praw autorskich, kopiowanie produktów, walka z konkurencją, niższe dochody przedsiębiorstwa.

Ostatni czynnik to certyfikacja:

- Charakterystyka czynnika: China CompulsoryCertificate to certyfikat obejmujący towary, których jakość oraz bezpieczeństwo używania są ważne dla konsumentów ${ }^{19}$.

- Powód wystąpienia: przepisy prawa, wprowadzenie wymogu uzyskania certyfikatu od 2003 roku.

- Wpływ czynnika na funkcjonowanie: procedura uzyskania certyfikatu wiąże się $\mathrm{z}$ wizytacją w przedsiębiorstwach chińskich inspektorów, a jej długotrwały czas oraz niejasność przepisów prawa mogą spowodować zahamowanie rozwoju działalności.

- Możliwe następstwa: konieczność dostosowania swoich produktów do standardów chińskich certyfikatów i innych przepisów prawa.

Tabela 1. Czynniki polityczno - prawne analizy PESTE

\begin{tabular}{|c|c|c|c|}
\hline $\begin{array}{c}\text { CZYNNIKI } \\
\text { POLITYCZNO-PRAWNE }\end{array}$ & TREND & $\begin{array}{c}\text { PRAWDOPODOBIEŃSTWO } \\
\text { przedzial }(0-1)\end{array}$ & $\begin{array}{c}\text { SILA } \\
\text { WPLYWU } \\
\text { przedzial } \\
(-5 \text { do }+5) \\
\end{array}$ \\
\hline \multirow[t]{3}{*}{ 1. Stabilność rządów } & wzrost & 0,3 & +5 \\
\hline & stabilizacj & 0,5 & +3 \\
\hline & regres & 0,2 & -2 \\
\hline \multirow{3}{*}{$\begin{array}{l}\text { 2. Relacje pomiędzy } \\
\text { Chinami a UE }\end{array}$} & wzrost & 0,3 & +4 \\
\hline & stabilizacj & 0,5 & +4 \\
\hline & regres & 0,2 & -3 \\
\hline \multirow{3}{*}{ 3. Poziom korupcji } & wzrost & 0,3 & -5 \\
\hline & stabilizacj & 0,4 & +4 \\
\hline & regres & 0,3 & +5 \\
\hline \multirow{3}{*}{ 4. Poziom biurokracji } & wzrost & 0,3 & -5 \\
\hline & stabilizacj & 0,5 & +4 \\
\hline & regres & 0,3 & +5 \\
\hline
\end{tabular}

\footnotetext{
${ }^{18}$ Prawo własności intelektualnej w

Chinach,http://www.gochina.gov.pl/index/?id=642e92efb79421734881b53e1e1b18b6, 28.01.2016.

${ }^{19}$ Wymagane

certyfikaty,http://www.gochina.gov.pl/index/?id=f7177163c833dff4b38fc8d2872f1ec6, 28.01.2016.
} 


\begin{tabular}{|l|c|c|c|}
\hline \multirow{3}{*}{ 5. System podatkowy } & wzrost & 0,4 & -5 \\
\cline { 2 - 4 } & stabilizacj & 0,4 & +4 \\
\cline { 2 - 4 } & regres & 0,2 & +4 \\
\hline \multirow{3}{*}{ 6. Prawa autorskie } & wzrost & 0,3 & +3 \\
\cline { 2 - 4 } & stabilizacj & 0,5 & +2 \\
\cline { 2 - 4 } & regres & 0,2 & +2 \\
\hline \multirow{2}{*}{ 7. Certyfikacja produktów } & wzrost & 0,3 & +2 \\
\cline { 2 - 4 } & stabilizacj & 0,5 & -4 \\
\cline { 2 - 4 } & regres & 0,2 & +4 \\
\hline
\end{tabular}

Źródło: opracowanie własne.

Wyniki dokonanych analiz przedstawione zostały w tabeli 1.

Następny obszar zawiera czynniki ekonomiczne:

- tempo wzrostu gospodarczego,

- stopa inflacji,

- cykl koniunkturalny,

- okoliczności wejścia na rynek nowych przedsiębiorstw,

- kursy walut,

- polityka fiskalna,

- koszty pracy,

- poziom bezrobocia.

Obszar społeczno - kulturowy to następujące czynniki:

- demografia prowincji Hubei,

- poziom wykształcenia,

- nowe wzorce konsumpcji,

- styl życia,

- zmiana modelu rodziny,

- współczynnik urbanizacji,

- sposób spędzania wolnego czasu,

- nowi klienci,

- przychody i wydatki chińskich gospodarstw domowych.

Obszar technologiczny obejmuje:

- rozwój technologii, inteligentne zarządzanie,

- zwiększenie łączności,

- Internet, jako kanał dystrybucji,

- udoskonalanie technologiczne systemu transportu.

Ostatni obszar to czynniki środowiskowe, z którymi Chiny mają poważne problemy. Wpływ na obecną sytuację ma związek z polityką szybkiego rozwoju gospodarczego, która była realizowana bez uwzględnienia skutków ubocznych. Według danych Banku Światowego, jedynie 1\% miast chińskich spełnia standardy Światowej Organizacji Zdrowia. Zwracając uwagę na tak poważną sytuację, rząd Chin zdecydował się na wprowadzenie niezbędnych zmian mających na celu zapobieganie dalszemu zanieczyszczaniu środowiska. W sferze ochrony środowiska przyjętych zostało ponad 40 
ustaw i innych uregulowań prawnych, zmierzających do ograniczenia emisji dwutlenku węgla. Wprowadzono również 5-letni (2016 - 2020) Plan Ochrony Środowiska, który koncentruje się na następujących zadaniach strategicznych: wprowadzenie systemu kontroli zanieczyszczeń, poprawa jakości środowiska, implementacja reguł zrównoważonego rozwoju. W analizie tego obszaru uwzględniono:

- wpływ procesu dystrybucji towarów na zmiany klimatyczne,

- $\quad$ wpływ realizacji inwestycji na wzmożony ruch pojazdów,

- wpływ inwestycji na zmiany krajobrazowe,

- funkcjonowanie przedsiębiorstwa a polityka recyklingu.

Kolejnym etapem analizy jest opracowanie scenariuszy: optymistycznego (tabela 2), pesymistycznego (tabela 3) oraz najbardziej prawdopodobnego (tabela 4).

Tabela 2. Scenariusz optymistyczny

\begin{tabular}{|c|c|}
\hline Elementy scenariusza optymistycznego & Sila wpływu \\
\hline \begin{tabular}{cl} 
& \multicolumn{1}{c}{ Kryterium polityczno - prawne } \\
- & większa stabilność rządów, \\
- & poprawa relacji między Chinami a Unią Europejską, \\
- & spadek poziomu korupcji, \\
- & spadek poziomu biurokracji, \\
- & obniżenie podatków, \\
- & uregulowanie sprawy praw autorskich, \\
- & ułatwienie procedury certyfikacji produktów. \\
& \multicolumn{1}{c}{ Średnia sila wpływu }
\end{tabular} & $\begin{array}{l}+5 \\
+4 \\
+5 \\
+5 \\
+4 \\
+3 \\
+4 \\
+\mathbf{+ 4 , 2 9}\end{array}$ \\
\hline \begin{aligned} & \multicolumn{1}{c}{ Kryterium ekonomiczne } \\
- & szybsze tempo wzrostu gospodarczego, \\
- & stabilizacja poziomu stopy inflacji, \\
- & wzrost cyklu koniunkturalnego, \\
- & korzystniejsze okoliczności wejścia na rynek nowych \\
& przedsiębiorstw, \\
- & stabilizacja poziomu kursów walut, \\
- & stabilizacja polityki fiskalnej, \\
- & obniżenie kosztów pracy, \\
- & spadek poziomu bezrobocia. \\
& \multicolumn{1}{c}{ Średnia siła wpływu }\end{aligned} & $\begin{array}{c}+5 \\
+4 \\
+4 \\
+4 \\
\\
+4 \\
+3 \\
+4 \\
+5 \\
+\mathbf{4 , 1 2}\end{array}$ \\
\hline \begin{tabular}{cl}
- & \multicolumn{1}{c}{ Kryterium spoleczno - kulturowe } \\
- & dodatni współczynnik demografiiw prowincji Hubei, \\
- & wzrost poziomu wykształcenia, \\
- & wzrost zainteresowania nowymi trendami, \\
- & nowe wzorce konsumpcji, \\
- & pozytywna zmiana modelu rodziny, \\
- & wzrost współczynnika urbanizacji, \\
- & wzrost liczby nowych klientów, \\
- & wzrost przychodów i wydatków gospodarstw domowych. \\
& \multicolumn{1}{c}{ Średnia sila wplywu } \\
\end{tabular} & $\begin{array}{c}+4 \\
+5 \\
+4 \\
+3 \\
+1 \\
+4 \\
+3 \\
+5 \\
+5 \\
+\mathbf{3 , 7 8}\end{array}$ \\
\hline $\begin{array}{c}\text { Kryterium technologiczne } \\
-\quad \text { rozwój technologii i inteligentnego zarządzania, }\end{array}$ & $\begin{array}{l}+4 \\
+4 \\
\end{array}$ \\
\hline
\end{tabular}




\begin{tabular}{|c|c|c|}
\hline $\begin{array}{l}- \\
- \\
-\end{array}$ & $\begin{array}{l}\text { rozwój łączności, } \\
\text { rozwój Internetu jako kanału dystrybucji, } \\
\text { udoskonalanie technologiczne systemu transportu. } \\
\qquad \text { Średnia sila wplywu }\end{array}$ & $\begin{array}{l}+4 \\
+4 \\
+4\end{array}$ \\
\hline- & $\begin{array}{l}\text { Kryterium środowiskowe } \\
\text { zmniejszenie niekorzystnego wpływu procesu dystrybucji } \\
\text { towarów na zmiany klimatyczne, } \\
\text { zmniejszenie niekorzystnego wpływu realizacji inwestycji na } \\
\text { wzmożony ruch pojazdów, } \\
\text { zmniejszenie niekorzystnego wpływu inwestycji na zmiany } \\
\text { krajobrazowe, } \\
\text { odpowiednia polityka recyklingu. } \\
\text { Średnia siła wpływu }\end{array}$ & $\begin{array}{l}+5 \\
+5 \\
+4 \\
+2 \\
+4\end{array}$ \\
\hline
\end{tabular}

Źródło: opracowanie własne.

Tabela 3. Scenariusz pesymistyczny

\begin{tabular}{|c|c|}
\hline Elementy scenariusza pesymistycznego & Sila wpływu \\
\hline \begin{tabular}{cl} 
& \multicolumn{1}{c}{ Kryterium polityczno - prawne } \\
- & mniejsza stabilność rządów, \\
- & pogorszenie relacji między Chinami a Unią Europejską, \\
- & wzrost poziomu korupcji, \\
- & wzrost poziomu biurokracji, \\
- & wzrost podatków, \\
- & brak uregulowania sprawy praw autorskich, \\
- & skomplikowanie procedury certyfikacji produktów. \\
& \multicolumn{1}{|c}{ Średnia sila wplywu }
\end{tabular} & $\begin{array}{l}-2 \\
-3 \\
-5 \\
-5 \\
-5 \\
-2 \\
-4 \\
-\mathbf{3 , 7 1}\end{array}$ \\
\hline \begin{tabular}{ll}
\multicolumn{1}{c}{ Kryterium ekonomiczne } \\
$-\quad$ & spadektempa wzrostu gospodarczego, \\
- & wzrost poziomu stopy inflacji, \\
- & spadekcyklu koniunkturalnego, \\
- & pogorszenieokoliczności wejścia na rynek nowych \\
& przedsiębiorstw, \\
- & wzrost wahań poziomu kursów walut, \\
- & wzrost regulacji w obszarzepolityki fiskalnej, \\
- & wzrostkosztów pracy, \\
- & wzrostpoziomu bezrobocia. \\
& \multicolumn{1}{c}{ Średnia sila wpływu } \\
\end{tabular} & $\begin{array}{c}-4 \\
-3 \\
-4 \\
-4 \\
\\
-3 \\
-2 \\
-3 \\
-4 \\
-\mathbf{3 , 3 8}\end{array}$ \\
\hline \begin{tabular}{cl} 
& \multicolumn{1}{c}{ Kryterium spoleczno - kulturowe } \\
- & ujemny współczynnik demografiiw prowincji Hubei, \\
- & obniżeniepoziomu wykształcenia, \\
- & zmniejszenie zainteresowania nowymi trendami, \\
- & nowe wzorce konsumpcji, \\
- & negatywnezmiany modelu rodziny, \\
- & spadekwspółczynnika urbanizacji, \\
- & sposób spędzania wolnego czasu, \\
- & spadek liczby nowych klientów, \\
- & spadekprzychodów i wydatków gospodarstw domowych. \\
& \multicolumn{1}{c}{ Średnia sila wplywu } \\
\end{tabular} & $\begin{array}{c}-5 \\
-5 \\
-4 \\
-2 \\
-3 \\
-4 \\
-5 \\
-4 \\
-4 \\
-\mathbf{4 , 1 1}\end{array}$ \\
\hline $\begin{array}{c}\text { Kryterium technologiczne } \\
-\quad \text { zahamowanie rozwoju technologii i inteligentnego }\end{array}$ & -3 \\
\hline
\end{tabular}




\begin{tabular}{|c|c|}
\hline $\begin{array}{l}\text { zarządzania, } \\
-\quad \text { zahamowanie rozwoju łączności, } \\
-\quad \text { zahamowanie rozwojuInternetu jako kanału dystrybucji, } \\
-\quad \text { zahamowanie udoskonalania technologicznego systemu } \\
\text { transportu. }\end{array}$ & $\begin{array}{l}-3 \\
-3 \\
-4 \\
-3,25\end{array}$ \\
\hline \begin{tabular}{ll}
\multicolumn{1}{c}{ Kryterium środowiskowe } \\
- & większy wpływprocesu dystrybucji towarów na zmiany \\
klimatyczne, \\
$-\quad$ większywpływ realizacji inwestycji na wzmożony ruch \\
pojazdów, \\
$-\quad$ zwiększeniewpływu inwestycji na zmiany krajobrazowe, \\
$-\quad$ zaostrzona polityka recyklingu. \\
Średnia siła wpływu
\end{tabular} & $\begin{array}{c}-5 \\
-5 \\
-4 \\
-2 \\
\mathbf{- 3 , 7 5}\end{array}$ \\
\hline
\end{tabular}

Źródło: opracowanie własne.

Tabela 4. Scenariusz najbardziej prawdopodobny

\begin{tabular}{|c|c|c|c|}
\hline $\begin{array}{c}\text { Elementy scenariusza najbardziej } \\
\text { prawdopodobnego }\end{array}$ & $\begin{array}{l}\text { Prawdopo- } \\
\text { dobieństwo }\end{array}$ & $\begin{array}{c}\text { Sila wplywu } \\
+\end{array}$ & $\begin{array}{c}\text { Sila wplywu } \\
-\end{array}$ \\
\hline $\begin{array}{l}\text { Kryterium polityczno - prawne } \\
-\quad \text { stabilność rządów, } \\
-\quad \text { stabilizacja relacji między Chinami } \\
\text { a Unią Europejską, } \\
-\quad \text { stabilizacja poziomu korupcji, } \\
-\quad \text { stabilizacja poziomu biurokracji, } \\
-\quad \text { stabilizacja podatków, } \\
-\quad \text { uregulowanie sprawy praw } \\
\text { autorskich, } \\
-\quad \text { uregulowanie procedury certyfikacji } \\
\text { produktów. } \\
\quad \text { Średnia sila wpływu }\end{array}$ & $\begin{array}{l}0,5 \\
0,5 \\
0,4 \\
0,5 \\
0,4 \\
0,5 \\
0,5\end{array}$ & $\begin{array}{l}+3 \\
+4 \\
+4 \\
+4 \\
+2 \\
+2 \\
+3,17\end{array}$ & 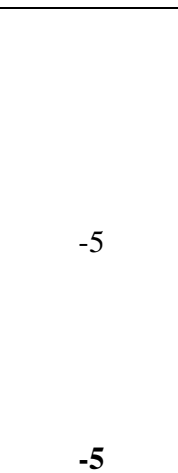 \\
\hline $\begin{array}{ll} & \text { Kryterium ekonomiczne } \\
- & \text { stabilizacjatempa wzrostu } \\
& \text { gospodarczego, } \\
- & \text { stabilizacja poziomu stopy inflacji, } \\
- & \text { wzrost cyklu koniunkturalnego, } \\
- & \text { stabilizacja warunków wejścia na } \\
& \text { rynek nowych przedsiębiorstw, } \\
- & \text { stabilizacja poziomu kursów walut, } \\
- & \text { stabilizacja polityki fiskalnej, } \\
- & \text { wzrostkosztów pracy, } \\
- & \text { spadek poziomu bezrobocia. } \\
& \text { Średnia sila wplywu }\end{array}$ & $\begin{array}{l}0,4 \\
\\
0,4 \\
0,4 \\
0,4 \\
\\
0,4 \\
0,4 \\
0,5 \\
0,5\end{array}$ & $\begin{array}{c}+4 \\
+4 \\
+4 \\
+3 \\
+4 \\
+3 \\
+5 \\
+3,85\end{array}$ & $\begin{array}{l}-2 \\
-2\end{array}$ \\
\hline 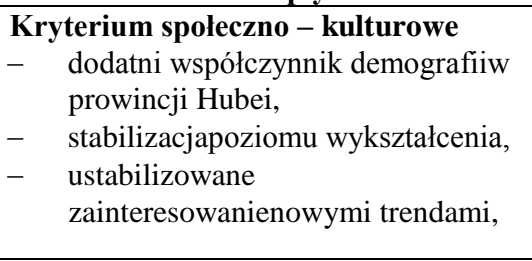 & $\begin{array}{l}0,4 \\
0,4 \\
0,4 \\
0,6\end{array}$ & $\begin{array}{l}+1 \\
+3 \\
\end{array}$ & -2 \\
\hline
\end{tabular}




\begin{tabular}{|c|c|c|c|}
\hline $\begin{array}{ll}- & \text { nowe wzorce konsumpcji, } \\
- & \text { pozytywna zmiana modelu rodziny, } \\
- & \text { wzrost współczynnika urbanizacji, } \\
- & \text { sposób spędzania wolnego czasu, } \\
- & \text { stabilizacja liczby nowych } \\
& \text { klientów, } \\
- & \text { stabilizacjaprzychodów i wydatków } \\
& \text { gospodarstw domowych. } \\
& \text { Średnia sila wpływu }\end{array}$ & $\begin{array}{l}0,4 \\
0,6 \\
0,4 \\
0,4 \\
0,6\end{array}$ & $\begin{array}{l}+1 \\
+4 \\
+2 \\
+3 \\
+2 \\
+2,5\end{array}$ & -2 \\
\hline $\begin{array}{ll} & \text { Kryterium technologiczne } \\
- & \text { stabilizacja rozwoju technologii i } \\
& \text { inteligentnego zarządzania, } \\
- & \text { stabilizacja rozwoju łączności, } \\
- & \text { rozwój Internetu jako kanału } \\
& \text { dystrybucji, } \\
-\quad & \text { stabilizacja technologicznego } \\
& \text { systemu transportu. } \\
& \text { Średnia sila wplywu }\end{array}$ & $\begin{array}{l}0,5 \\
0,6 \\
0,5 \\
0,6\end{array}$ & $\begin{array}{r}+4 \\
+3 \\
+4 \\
+3 \\
+3,5\end{array}$ & \\
\hline $\begin{array}{ll}\text { Kryterium środowiskowe } \\
\text { - } & \text { stabilizacjawpływu procesu } \\
\text { dystrybucji towarów na zmiany } \\
\text { klimatyczne, } \\
\text { - } \\
\text { stabilizacjawpływu realizacji } \\
\text { inwestycji na wzmożony ruch } \\
\text { pojazdów, } \\
\text { - stabilizacjawpływu inwestycji na } \\
\text { zmiany krajobrazowe, } \\
\text { umiarkowana polityka recyklingu. } \\
\text { Średnia sila wpływu }\end{array}$ & $\begin{array}{l}0,4 \\
0,4 \\
0,4\end{array}$ & $\begin{array}{c}+3 \\
+3 \\
+3 \\
+\mathbf{2 , 7 5}\end{array}$ & \\
\hline
\end{tabular}

Źródło: opracowanie własne.

Tabela 5. Zestawienie średnich sił wpływu w badanych obszarach

\begin{tabular}{|c|c|c|c|c|}
\hline & $\begin{array}{c}\text { scenariusz } \\
\text { pesymistyczny }\end{array}$ & $\begin{array}{c}\text { scenariusz } \\
\text { optymistyczny }\end{array}$ & $\begin{array}{c}\text { scenariusz } \\
\text { najbardziej } \\
\text { prawdopodobny } \\
-\end{array}$ & $\begin{array}{c}\text { scenariusz } \\
\text { najbardziej } \\
\text { prawdopodobny } \\
+\end{array}$ \\
\hline $\mathbf{P}$ & $-3,71$ & 4,29 & -5 & 3,17 \\
\hline $\mathbf{E}$ & $-3,38$ & 4,12 & -2 & 3,85 \\
\hline $\mathbf{S}$ & $-4,11$ & 3,78 & -2 & 2,5 \\
\hline $\mathbf{T}$ & $-3,25$ & 4 & 0 & 3,5 \\
\hline $\mathbf{E}$ & $-3,75$ & 4 & 0 & 2,75 \\
\hline
\end{tabular}

Źródło: opracowanie własne.

Po stworzeniu poszczególnych scenariuszy dokonano zestawienia (tabela 5) średnich sił wpływu w analizowanych obszarach: polityczno-prawnym $(\mathrm{P})$, ekonomicznym $(\mathrm{E})$, 
społeczno-kulturowym (S), technologicznym (T) oraz środowiskowym (E), a następnie na tej podstawie wyniki zobrazowano w formie graficznej (rysunek 1).

$\mathrm{Na}$ podstawie analizy poszczególnych tabel i zawartych w nich scenariuszy oraz wykresu można sformułować następujące wnioski:

- największą rozpiętość stwierdzono pomiędzy scenariuszami pesymistycznym oraz optymistycznym w obszarzepolityczno - prawnymispołeczno - kulturowym, co może oznaczać mocny wpływ zdarzeń w otoczeniu na przedsiębiorstwo. Strefa ta określana jest jako wzburzona, wymagająca szczególnej obserwacji dlatego wskazanesą dalsze analizy,

- najmniejsza rozpiętość występuje pomiędzy scenariuszem pesymistycznym oraz optymistycznym w obszarze technologicznym,

- brak scenariusza najbardziej prawdopodobnego ujemnego (-) w obszarach: technologicznym oraz środowiskowym,

- największa rozpiętość pomiędzy scenariuszami najbardziej prawdopodobnymi dodatnim (+) oraz ujemnym (-) istnieje w obszarze polityczno - prawnym oraz ekonomicznym, z zaznaczeniem iż stosunkowo duża rozpiętość dostrzegana jest we wszystkich obszarach, coświadczy o znacznej heterogeniczności otoczenia i konieczności dokładniejszej analizy.

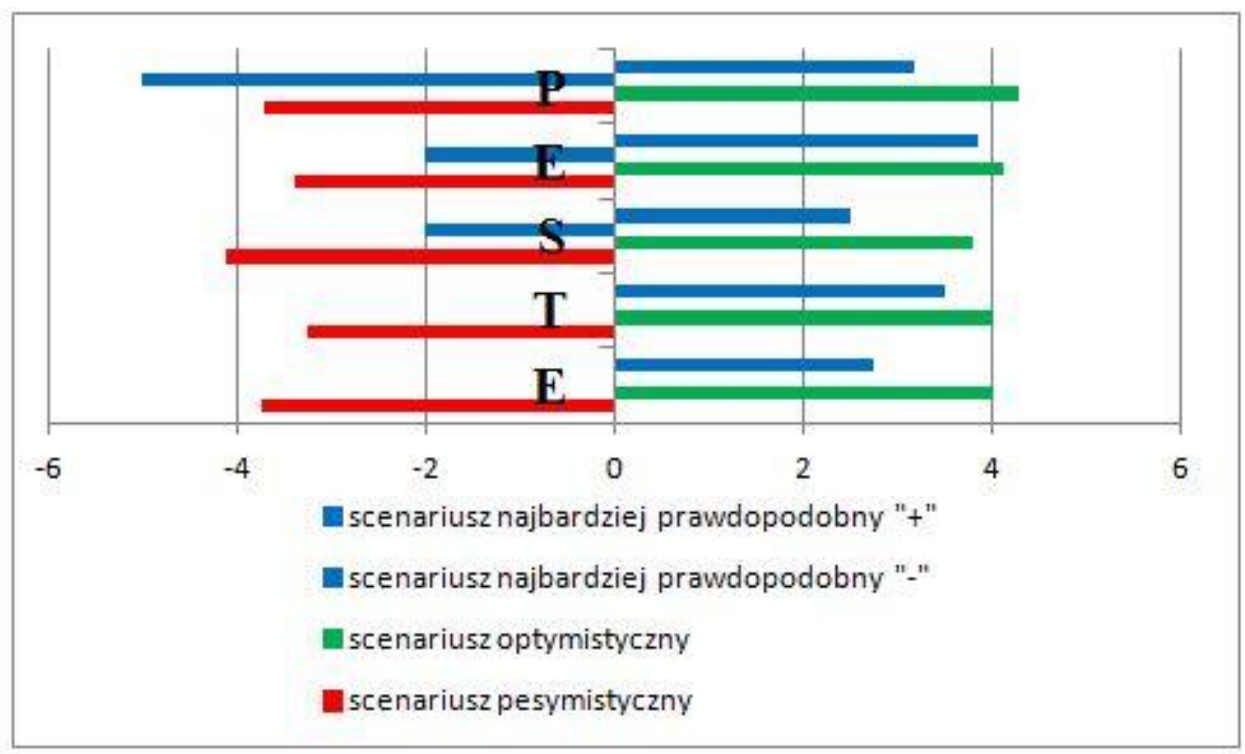

Rysunek1.Zestawienie opracowanych scenariuszy Źródło: opracowanie własne.

Przeprowadzone badania poszczególnych obszaróworazzbudowanie i następnie analiza scenariuszy pozwala na uzyskanie dokładnego i szczegółowego obrazu stanu otoczenia przedsiębiorstwa. 


\section{ZAKOŃCZENIE}

Funkcjonowanie przedsiębiorstwa na różnorodnych rynkach światowych wymaga odpowiedniego przygotowania się do rozpoczęcia działalności, budowy nowego zakładu lub centrum logistycznego.Szczególnie dotyczy to podjęcia decyzji lokalizacyjnej centrum logistycznego w kraju, który znacznie różni się w obszarze politycznym, ekonomicznym, środowiskowym i kulturowym od rozwiązań stosowanych w państwie siedzibie danej firmy.

Przedsiębiorstwo zarówno produkcyjne jak i dystrybucyjne nie może stworzyć strategii działania nie biorąc pod uwagę sytuacji ekonomicznej danego kraju czy regionu, w którym chce funkcjonować. Przykładem mogą być koszty pracy, które wposzczególnychkrajach oraz częściach świata są różne. Należy uwzględnić również spektrum decyzji politycznych oraz przepisy prawa. Przedsiębiorstwa, które funkcjonują na rynku międzynarodowym muszą liczyć się z tym, iż w różnych częściach świata stanowione prawo jest odmienne. Ważnym aspektem jest także społeczeństwo, jego nastroje, przyzwyczajenia, aktualnie panujące treny mody oraz demografia.Wszystko to wpływa na aktualny oraz przyszły popyt. Rozwój technologiczny oraz aspekty związane z ochroną środowiska również odgrywają zasadniczą rolę w decyzjach dotyczących rozwoju przedsiębiorstwa.

Istnieją różne metody wyznaczania lokalizacji centrum logistycznego, ale najlepszym sposobem jest analiza otoczenia oraz ocena możliwości funkcjonowania danej firmyna określonym rynku z wykorzystaniem metody PESTE, która pozwala na kompleksową oraz szczegółową ocenę poszczególnych obszarów i czynników lokalizacji i w efekcie wybór najlepszego miejsca na wybudowanie i funkcjonowanie centrum logistycznego.

\section{LITERATURA}

[1] Fechner I., Centra logistyczne. Cel - Realizacja - Przyszłość, ILiM, Poznań 2004,

[2] Obłój K., Strategia Organizacji. $W$ poszukiwaniu trwałej przewagi konkurencyjnej, PWE, Warszawa 2007,

[3] Malindžák D., Gazda A., Podstawy logistyki w przedsiębiorstwie, Oficyna Wydawnicza Politechniki Rzeszowskiej, Rzeszów 2011.

[4] Skowron-Grabowska B., Centra logistyczne w tańcuchach dostaw, PWE Warszawa 2010,

[5] China,gdp-per-capita-ppp, http://www.tradingeconomics.com/, 29.12.2015.

[6] Chinas-levels-of-bureaucracy-have-gotten-ridiculous, http://blogs.wsj.com/chinarealtime/2015/04/17/chinas-levels-of-bureaucracyhave-gotten-ridiculous-premier-says/, 19.01.2016,

[7] Chiny. Ustrój polityczny, http://encyklopedia.pwn.pl/haslo/Chiny-Ustrójpolityczny;4573926.html, 16.01.2016,

[8] Copyright_Guide, http://www.chinaiprhelpdesk.eu/sites/all/docs/publications/PL_Copyright_Guide_Aug_2010.p df, 27.01.2016,

[9] Corruption Perceptions Index, http://www.transparency.org/cpi2015, 18.01.2016, 
[10]Countries and regions, China, http://ec.europa.eu/trade/policy/countriesand-regions/countries/china/, 18.01.2016,

[11] Informacje na temat chińskiego prawa gospodarczego, http://www.gochina.gov.pl/index/?id=17e62166fc8586dfa4d1bc0e1742c08b, 23.01.2016,

[12] Prawo własności intelektualnej w Chinach, http://www.gochina.gov.pl/index/?id=642e92efb79421734881b53e1e1b18b6 , 28.01.2016,

[13] System podatkowy, https://mfiles.pl/pl/index.php/System_podatkowy, 23.01.2016,

[14] Transparency International, https://pl.wikipedia.org/wiki/Transparency_International, 18.01.2016,

[15] Wymagane certyfikaty, http://www.gochina.gov.pl/index/?id=f7177163c833dff4b38fc8d2872f1ec6, 28.01.2016

\section{LOCATION FACTORS OF LOGISTICS CENTER IN CHINESE MARKET WITH AN} APPLICATION OF PESTE METHOD

The Chinese market since 1978, so since the start of transition and reform in China, opened up widely to international trade, and economic growth in this country has increased significantly. According to the gross domestic product (GDP) per capita, China shows a steady increase. Chinese gross domestic product per capita adjusted to purchasing power parity in 2014 was $\$ 12,608.87$ and the average GDP per capita from 1990 to 2014 amounted to $\$ 5,476.62$. Although in recent years the pace of GDP growth has been weaker, still the domestic and international trade generate demand for the construction of logistics centers, or spatial objects that meet specific functions, along with the appropriate organization and infrastructure. There are run various logistics services, which include: storage, separation, receiving and issuing goods. Typical logistics center should, therefore, have facilities such as warehouses, railway container terminals, storage areas, as well as the place of supply of services, customs and others. The location of centers can be determined by conventional methods. Well-known and most widely used methods of supporting the process of determining the location of the logistics center include the following: the method of non-hierarchical cluster analysis, transformed into a formula transport problem, i.e. the Huff's model and determination of the radius catchment areas. Whereas the method which comprehensively allows to take into account a variety of factors influencing the location is PESTE.

Keywords: logistics center, location factors, PESTE method.

DOI:10.7862/rz.2016.hss.40

Przesłano do redakcji: styczeń 2016

Przyjęto do druku: wrzesień 2016 